\title{
MEDIA A ZJAWISKO AGRESJI W SPORCIE
}

We współczesnych mediach masowych teksty pokazujące - opisujące agresję, stanowią istotną form przekazu prasowego. ${ }^{1}$ Nie inaczej jest też w dziennikarstwie sportowym. Relacje niejednokrotnie koncentrują się na elementach intrygujących i kontrowersyjnych, współzawodnictwie dalekim od zasad fair play.

Sport jako szeroko pojęte zjawisko to temat niezwykle atrakcyjny dla mediów, jest bowiem rodzajem aktywności, która budzi zróżnicowane, skrajne emocje. $\mathrm{Z}$ jednej strony zachwyca i fascynuje, pozwala eksponować możliwości ludzkiego ciała, z drugiej strony może budzić złość i frustrację, zarówno zawodnika, jak i kibica. Zmaganiom najczęściej towarzyszą łzy szczęścia, ale i rozpaczy, gesty triumfu i niezadowolenia. We współczesnym sporcie liczy się przede wszystkim wygrana, najbliższe otoczenie zawodnika, jego klub lub zespół, mało kto pamięta o idei samego udziału w zawodach. W efekcie generuje to różne postawy i zachowania, które nie zawsze powinny stanowić dominantę kompozycyjną materiałów dziennikarskich. Jak pisał jeden z polskich badaczy: „Otaczający nas sport wymyka się coraz bardziej spod wpływów pedagogiki. Z jednej strony jest polem afer dopingowych, poddawany jest wpływom komercjalizacji, manipulacji i eksploatacji przez mass media, z drugiej zaś stał się schroniskiem dla młodzieżowych subkultur,

\footnotetext{
* DR Olga BIAŁEK-SzWED - Instytut Dziennikarstwa i Komunikacji Społecznej KUL; o.bialek. szwed@wp.pl

${ }^{1}$ Agresja jest nie tylko problemem społecznym, ale również stwarza kłopoty leksykalne, definicyjne; bowiem jest terminem obszernym, pojawiającym się zarówno w opracowaniach naukowych, jak i w dyskursie publicznym. Najpopularniejszą definicją agresji jest ujmowanie jej jako zachowania, które nastawione jest na sprawienie bólu drugiemu człowiekowi, szczególnie gdy doprowadzenie do cierpienia stanowi jedyną intencję sprawcy. W niniejszym artykule agresja rozpatrywana jest na podobieństwo rozważań Elliota Aronsona, właśnie jako zachowanie lub ,akt mający na celu wyrządzenie szkody lub przykrości. (...) zgodnie z tą definicją, piłkarz nie dokonuje aktu agresji, jeśli ma na celu po prostu jak najskuteczniejsze powstrzymanie przeciwnika - natomiast zachowuje się agresywnie, jeśli jego celem jest wyrządzenie krzywdy lub sprawienie bólu przeciwnikowi." Agresja w sporcie może się przejawiać w różnych zachowaniach, takich jak: szarpanie, popychanie, uderzanie, podstawianie nogi, tarasowanie drogi itp. Zob. E. Aronson, Człowiek istota społeczna, Warszawa 1995, s. 300-304.
} 
pretekstem stadionowego buntu i w konsekwencji miejscem poważnych zaburzeń społecznych."2

Tematem niejednoznacznym, który nie zawsze powinien stać się punktem wyjścia dla newsa dziennikarskiego jest agresja. Agresja, która w niektórych dyscyplinach znajduje się niejako u ich podłoża (np. boks, kick-boxing, zapasy, judo, MMA, jujitsu, karate, taekwondo, sumo, krav maga, kendo, a nawet szermierka, czy futbol, rugby i hokej itp.), co jeszcze bardziej komplikuje materię i zapewne w dalszej perspektywie utrudnia pracę nie tylko mediów, ale także i arbitrów. Tym bardziej, że w wymienianych dyscyplinach, bez pewnej dawki agresji nie sposób jest osiągnąc sukces; nie da się też stworzyć oczekiwanego przez kibiców, sponsorów i oczywiście media widowiska. Agresja w tychże sportach, to też - zdaniem profesora Kazimierza Doktóra, kierownika Zakładu Systemów Zarządzania IFIS PAN oraz byłego członka Komitetu Olimpijskiego - ,(...) pochodna zasadniczej cechy sportu, która jest oparta na współzawodnictwie, na konkurencyjności, na rywalizacji. $\mathrm{Z}$ tego powodu nie powinniśmy się dziwić, że w pewnych obszarach pojawia się wyjątkowo mocna agresywność, bo na przykład nieagresywny bokser nie może wygrać, a zapaśnik, który nie atakuje, nie dostanie punktów."’3 Jak podkreślał profesor Doktór, czy tego chcemy czy nie, są takie dyscypliny ze swej natury, wręcz etiologicznie naznaczone agresją.

Jak ustaliły badaczki z Akademii Wychowania Fizycznego w Warszawie, Zuzanna Mazur i Natalia Organista, zachowania agresywne w sporcie występują w dwóch postaciach. Jeden rodzaj Mazur i Organista określały jako zachowania niedestruktywne, drugi zaś jako destruktywne. Jak tłumaczyły - „Te pierwsze utożsamiane są z asertywnością, charakteryzującą się samoobroną, niegniewnością i nastawieniem na osiągnięcie celów. Agresja destruktywna natomiast wyrażana jest w złości, zemście i wściekłości. Zawarta jest w niej intencja szkodzenia, lecz nie musi towarzyszyć temu siła fizyczna.." ${ }^{\prime 2} \mathrm{~W}$ podobny sposób widział przyczyny i skutki agresji destruktywnej (chociaż tak jej nie nazywał - przyp. O.B.S.) Elliot Aronson, co też opisał w swojej pracy Człowiek istota społecznas ${ }^{5}$.

Agresja w sporcie i zainteresowanie tym problemem - co warto podkreślić za Tomaszem Janusem - nie jest niczym nowym, ale kwestią sięgającą aż do starożytności. Janus w swojej dysertacji opisał między innymi to co w pierwszych wiekach pierwszego tysiąclecia działo się na arenach sportowych, na trybunach dla kibiców, w ówczesnych szatniach, czy też w relacjach interpersonalnych pomiędzy zawodnikami a ich trenerami, tudzież możnymi patronami. $Z$ rozprawy doktorskiej Tomasza Janusa z 2012 roku można się było dowiedzieć na przykład, że „w 523 r. n.e. rozruchy

2 W. Lipoński, Olimpizm dla każdego, Poznań 2000, s. 26.

${ }^{3}$ K. Jasiecki, Wyczyn, pieniadze, polityka, rozmowa z prof. K. Doktórem, www.decydent.pl/ meandry-sportu/, [dostęp dn. 9.06.2017].

${ }^{4}$ Z. Mazur, N. Organista, Poziom agresywności kobiet uprawiających sporty rodzajowo męskie $i$ kobiece, ,Journal of education, health and sport” vol. 5, nr 5 (2015), s. 154.

${ }^{5}$ E. Aronson, Człowiek istota społeczna, Warszawa 1995. 
wywołane przez niezadowolonych kibiców, prawie doprowadziły do obalenia cesarza Justyniana.", jak też wiele o fanatyzmie ówczesnych kibiców, czy zachowaniach zawodników nie mających nic wspólnego z ideą fair play - „Płonące ławy, bójki, interweniujące służby porządkowe - taki widok nie należał na starożytnych imprezach sportowych do rzadkości. Nie brakowało także sportowców, którzy gotowi byli podjąć wszelkie działania - z korupcją na czele - byle tylko na swą głowę włożyć wieniec zwycięstwa. Nie inaczej było w „dżentelmeńskim” czasie sportu na przełomie XIX i XX wieku. Również i wtedy nie brakowało agresji wśród sportowców, jak i kibiców. Do głosu dochodziły napięcia rasowe, narodowościowe czy religijne. Rzekomo spokojnych i kulturalnych przedstawicieli wyższych klas w melonikach, niejednokrotnie musiała uspokajać policja, a czasami rozpędzać bagnetami wojsko." ${ }^{6}$

Ryszard Kapuściński w jednym ze swoich reportaży opisał historię z 1969 roku, tzw. „Wojnę futbolową”, zwaną też „Wojną stu godzin”, która to udowadnia, jak bardzo sport uzależniony jest od lokalnej i globalnej polityki oraz od mediów. W 1969 roku miał miejsce mecz pomiędzy drużynami Hondurasu i Salwadoru, który to nie był zwykłym zmaganiem na boisku piłkarskim, ale meczem eliminacyjnym do mundialu 1970 roku w Meksyku. W owym czasie oba wymienione kraje były ze sobą skonfliktowane, co widać było zarówno w zachowaniach zawodników, jak i kibiców. Podstawą konfliktu była polityka, a konkretnie osadnictwo rolników z Salwadoru na terenach przygranicznych Hondurasu. Zjawisko to powodowało nieustanną, czasami brutalną walkę z osadnikami z Salwadoru sił rządowych Hondurasu. Mecz eliminacyjny był więc spotkaniem podwyższonego ryzyka, który w efekcie zakończył się wybuchem wojny ${ }^{7}$, ale jednocześnie przyczynił się do powstania licznych materiałów dziennikarskich, w tym też wspomnianego już reportażu Kapuścińskiego ${ }^{8}$; zgodnie z zasadą, iż działania agresywne budzą nieustanne zainteresowanie mediów.

Także i dzisiaj wizualizacje brutalnych, nieetycznych zachowań uczestników widowiska sportowego dynamizują materiały dziennikarskie, wzmagają zainteresowanie odbiorcy, bowiem - jak uważał Erich Fromm - są alternatywą dla nudy. Według Fromma - „Miliony ludzi ma płytką, ale dość komfortową egzystencję; nic nie podnieca ich bardziej niż oglądanie lub czytanie o zabijaniu, bez względu na to,

${ }^{6}$ T. Janus, Zjawisko agresji w widowiskach sportowych. Charakterystyka i ocena, rozprawa doktorska napisana w Katedrze Teologii Pastoralnej Fundamentalnej UKSW w Warszawie, pod kierunkiem ks. prof. J. Przybyłowskiego, Warszawa 2012, s. 7-8.

${ }^{7}$ Inny mecz piłki nożnej, podobnie uważany jest za symboliczny początek konfliktu zbrojnego, tym razem mającego miejsce na Bałkanach w pierwszej połowie lat 90. XX wieku (1991-1995) spotkanie drużyn pierwszej ligi jugosłowiańskiej chorwackiego Dinama Zagrzeb i serbskiej Crveny Zvezdy. Pod czas meczu doszło do zamieszek, które doprowadziły do przerwania rozgrywek. Media, nie tylko jugosłowiańskie, zwróciły uwagę na zachowanie piłkarza Dinama Zagrzeb, Zvonimira Bobana, który zaatakował policjanta bijącego kibica drużyny chorwackiej.

${ }^{8}$ R. Kapuściński, Wojna futbolowa, Warszawa 2003; zob. też Z. Ziątek, Miejsce wojny futbolowej w biografii twórczej Ryszarda Kapuścińskiego i w historii polskiego reportażu, [w:] I. Borkowski, K. Stasiuk-Krajewska, Kształtowanie wizerunku jako narzędzie public relations, Wrocław 2001, s. 193-204. 
czy jest to morderstwo, czy nieszczęśliwy wypadek w czasie wyścigu samochodowego." ${ }^{\prime 9}$ Współczesne media, zarówno prasa, telewizja, Internet, może nieco mniej radio, systematycznie dostarczają licznych informacji potwierdzających tezę postawioną przez Fromma. Odbiorca nieustannie epatowany jest niemal każdym wykroczeniem, zakłóceniem porządku przez kibiców, czy też agresywnymi zachowaniami sportowców.

Wszystkie większe imprezy sportowe oferują obok emocji, kolejnych rekordów, zaskakujących debiutów, także bogaty materiał, który może przyczynić się do aktualizacji badań naukowych analizujących poziom zachowań agresywnych wśród zawodników i kibiców. Ubiegłoroczne Igrzyska Olimpijskie Rio 2016 również odnotowały kilka przypadków nadających się do analizy. Jednym z nich był komentowany przez światowe media atak ukraińskiego kolarza, Andrija Hriwki. Hriwko uderzył łokciem w twarz swojego rywala niemieckiego sprintera, Marcela Kittela. Za ten wybuch agresji Ukrainiec został wyrzucony z wyścigu - Dubai Tour..$^{10}$ Przypadek konfliktu dwóch kolarzy jest interesujący, ponieważ zgodnie z zapewnieniami Ukraińca, agresor tylko odpowiedział na wcześniejsze zaczepki poszkodowanego. Jak tłumaczył w oświadczeniu dla mediów Hriwko - „Odpowiedziałem agresją na agresję z drugiej strony. Być może dałem się ponieść emocjom i nie miało to nic wspólnego z kolarstwem, ale w ekstremalnych sytuacjach, kiedy w grę wchodzą kwestie bezpieczeństwa, ciężko zachować spokój. (...) Uprawiam kolarstwo od 12. roku życia i tak jak wszyscy uważam za normalne, kiedy sprinterzy walczą o pozycję na $3 \mathrm{~km}$ przed metą. Ale kiedy dochodzi do tego na $100 \mathrm{~km}$ przed metą, w przesadnym stylu i w trudnych warunkach pogodowych, sprowadza to na kolarzy wielkie niebezpieczeństwo. W trakcie takiej walki o pozycję, co zostało potwierdzone przez Kittela, najpierw ostro potraktowany przez niego został mój kolega Dmitrij Gruzdew, a potem ja, co doprowadziło do napięcia i niebezpiecznej sytuacji, w wyniku której mogłem nie tylko upaść, ale i spowodować wielką kraksę w peletonie." $\mathrm{Z}$ oświadczenia Ukraińca dziennikarze mogli się również dowiedzieć, że oskarża on Niemca o narażenie życia i zdrowia innych kolarzy, o zachowanie niezgodne z przepisami, ale też o brak kultury - „splunął w moim kierunku (Kittel w stronę Hriwki - przyp. O.B.S.)". W komunikacie pojawiły się też przeprosiny Hriwki kierowane do organizatorów, kibiców i swojego zespołu. Media podzieliły się w ocenie sytuacji, zwracano uwagę, że konsekwencje poniósł zawodnik, który zastosował agresję fizyczną, czyli zdyskwalifikowany kolarz ukraiński. Natomiast ten, który wykazał się aroganckim i prowokacyjnym zachowaniem, już nie. Oznacza to, że organizatorzy, ale i większość dziennikarzy, zwróciło uwagę przede wszystkim na widoczne skutki zajścia - rozcięty łuk brwiowy Kittela.

Drugi przypadek pochodzący z Rio, który warto dostrzec, to przykład agresji zespołowej. Jest on szczególnie interesujący dla badaczy polskich, ponieważ dotyczy

${ }^{9}$ E. Fromm, Wojna w człowieku, Warszawa 1994, s. 30.

${ }_{10}$ Odpowiedziatem agresja na agresje. Hriwko nie przeprosi Kittela, www.eurosport.onet. $\mathrm{pl} /$ kolarstwo/odpowiedziałem-agresja-na agresję-hriwko-nie przeprosi-kittela/8px26w [dostęp dn. 9.06.2017]

${ }^{11}$ J.w. S. $1 / 2$. 
drużyny siatkarzy biało - czerwonych. Po wygranym przez siebie meczu (3:2) z Iranem, Polacy pozwolili sobie na niezbyt eleganckie zachowania (tj. obraźliwe gesty, a później ironiczne wypowiedzi) pod adresem drużyny rywali. Choć początkowo całe zajście w mediach przedstawiane było jako atak ze strony siatkarzy Iranu, którzy nie potrafią zaakceptować porażki, szybko okazało się jednak, że było inaczej. Jedno z udostępnionych $\mathrm{w}$ Internecie nagrań pokazało, że wina leżała po stronie dwóch polskich zawodników - Bartosza Kurka i Michała Kubiaka. Sprawę obszernie relacjonowały media światowe. Podczas konferencji prasowej dziennikarze pytali o szczegóły zajścia zawodników i ówczesnego trenera polskiej drużyny. Niestety Stephan Antiga dość niefortunnie próbował dyscyplinować nie swoich zawodników, ale zainteresowanych sprawą dziennikarzy, zwracając się do nich słowami: „Przestańcie pisać te głupoty. Porozmawiajmy w końcu o sporcie. Proszę was, żebyście nie robili z tego wielkich artykułów, napiszcie jedno zdanie. Moje zdanie jest takie, że to byłoby niedobre dla sportu. Ludzie powinni czytać o sporcie, o postawie sportowców." "12 Interwencja polskiego trenera odniosła skutek odwrotny, tematem zajęły się już nie tylko media tradycyjne, ale i społecznościowe. Konsekwencją zaistniałej sytuacji było pojawienie się nieprzyjemnych, agresywnych w treści (pojawiły się też groźby) wpisów na Instagramie prowadzonym przez fanów Michała Kubiaka. Ostatecznie sprawą zajęła się Międzynarodowa Federacja Piłki Siatkowej (FIVB).

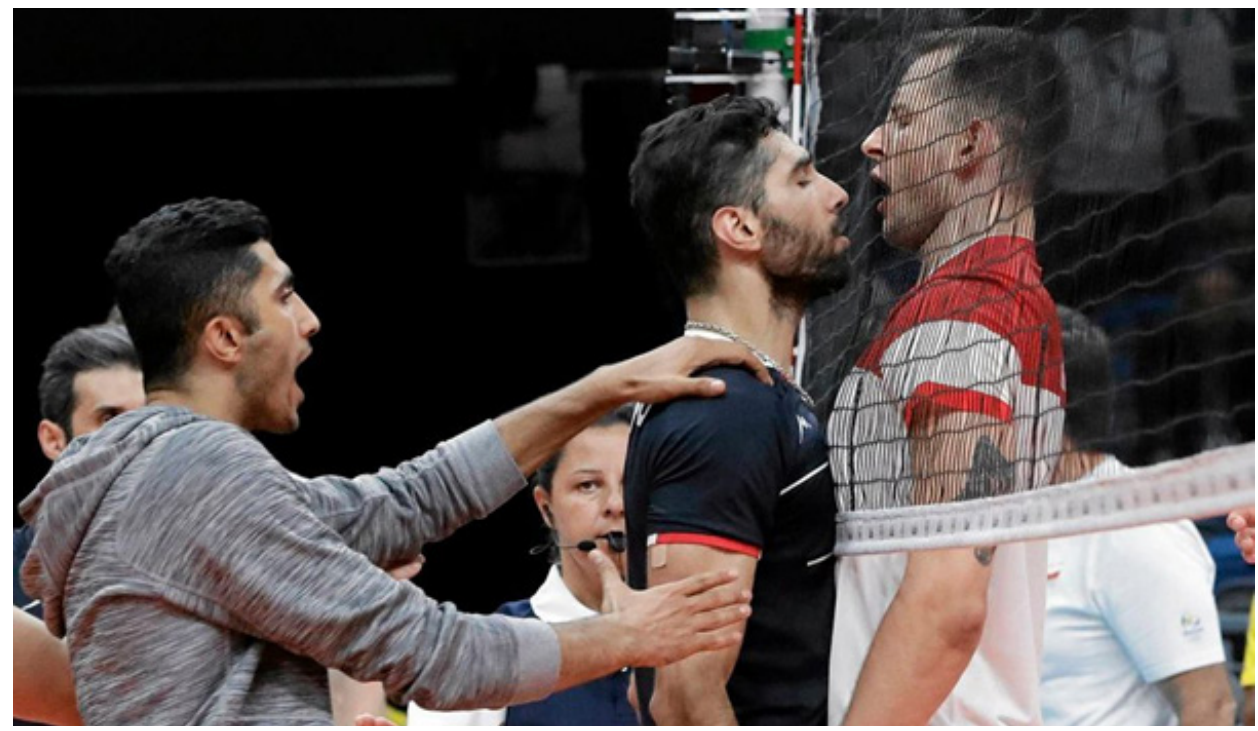

Fot. Jeff Roberson/AP; Rio 2016 - po meczu siatkówki Polska-Iran 3:2

${ }_{12}$ Awantura po meczu siatkarzy z Iranem. Trenerom i zawodnikom puścity nerwy, www.sport. dziennik.pl/siatkowka/artykuly/528406, [dostęp dn.9.06.2017]; zob też Rio 2016. Polska - Iran. Irańscy kibice strasza Michała Kubiaka,www.sport.pl/igrzyska-olimpijskie/1,154863,20524603, [dostęp 9.06.2017]; Rio 2016: obraźliwe gesty polskich siatkarzy przyczyna awantury po meczu z Iranem?, www.eurosport.onet.pl/rio-2016/siatkowka/rio-2016, [dostęp 9.06.2017]. 
Zygmunt Freud zainteresowanie informacjami zawierającymi elementy agresji uznawał za naturalną potrzebę człowieka. ${ }^{13}$ Jerzy Pomorski i Zbigniew Nęcki, potrzebę stałej percepcji obrazów prezentujących agresję również wiązali z biologią człowieka, która - jak obaj zauważyli - zawsze determinowała go do rozszyfrowywania właśnie informacji negatywnych. Zdaniem Pomorskiego i Nęckiego wydawcy kolportując różne obrazy agresji jedynie wychodzą naprzeciw zapotrzebowaniom czytelników. Na ten sam element zwróciła też uwagę Janina Fras, pisząc: „Najnowsze badania pracy mózgu i mechanizmów pamięci wykazały, że mózg ludzki jest bardziej nastawiony na zapamiętywanie tego, co sensacyjne i niezwykłe, niż tego, co codzienne i stale dozowane."'14. A Marshall McLuhan głosił, że „prawdziwe wiadomości to złe wiadomości” ${ }^{15 .}$ Nie żyjący już abp lubelski, Józef Życiński, który znał i rozumiał specyfikę mediów, w jednej ze swoich książek stwierdził że „swoiste prawo przepływu informacji sprawia, że znacznie częściej i głośniej mówi się o tym, co prymitywne, cyniczne i puste niż o tym, co szlachetne i piękne. Zło ze swej natury jest agresywne i krzykliwe. Dobro zaś może zostać łatwo uznane za nudne."” Życiński w swoich rozważaniach zwracał uwagę na fakt, iż agresja niezależnie od swojej proweniencji, zgodnie z nauczaniem Kościoła katolickiego nigdy nie powinna znaleźć akceptacji. W podobny sposób, nie dając przyzwolenia na zło w sporcie, wypowiadał się papież Jan Paweł II. Św. Jan Paweł II podkreślał, że „przemoc jest zawsze obrazą, ubliżeniem człowiekowi, zarówno temu, który jest sprawcą, jak i temu, który jest jej ofiarą. Przemoc jest niedorzecznością, ogromnym absurdem, zwłaszcza gdy ma miejsce podczas zawodów sportowych." ${ }^{17}$ Jak wiadomo jednak słowa i myśli papieża - Polaka, nie tylko te odnoszące się do agresji w sporcie, nie zawsze chciały być rozumiane, a co więcej nie zawsze były stosowane w rzeczywistości, mimo deklaracji i zapewnień wiernych.

Tak więc, paradoksalnie zła wiadomość była, jest i prawdopodobnie nadal będzie dla mediów wiadomością dobrą, zgodnie z niepisaną zasadą dziennikarstwa newsowego, która jak najbardziej sprawdza się też w wydaniu masowym współczesnego dziennikarstwa sportowego. Bójki i inne agresywne zachowania zawodników wzbudzają nie mniejsze zainteresowanie czytelników niż same wydarzenia sportowe. Jakże daleko jest materiałom dziennikarskim prezentującym powyższą perspektywę do wzorcowych, klasycznych artykułów sportowych, skoncentrowanych na propagowaniu uniwersalnych wartości znajdujących się w różnych dyscyplinach sportu,

${ }^{13}$ Zob. W. L. Rivers, C. Mathews, Etyka środków przekazu, Warszawa 1995, s. 69.

14 J. Fras, Dziennikarski warsztat językowy, Wrocław 1999, s. 78.

15 M. McLuhan, Zrozumieć media. Przedlużenia człowieka, Warszawa 2004, s. 227.

16 Abp J. Życiński, Kuszenie Pana Cogito, Lublin 2001, s. 140.

17 Jan Paweł II, Przemówienie do członków sportowej Fundacji Luciano Re Cecconi, Rzym 28.01.1980, za T. Janus, Zjawisko agresji w widowiskach sportowych. Charakterystyka i ocena, rozprawa doktorska napisana w Katedrze Teologii Pastoralnej Fundamentalnej UKSW w Warszawie, pod kierunkiem ks. prof. J. Przybyłowskiego, Warszawa 2012. 
takich jak elementy edukacyjne, wychowawcze, socjalizacyjne, prospołeczne itp. oraz na idei ruchu olimpijskiego z jego naczelną zasadą fair play.

Agresja w mediach zajmujących się sportem miewa różne oblicza, pojawia się w kontekście wielu zjawisk przekraczających ogólnie ustalone normy współżycia społecznego, rywalizacji sportowej, idei olimpizmu, zasad fair play. Celem przemocy, podglądanej i opisywanej przez dziennikarzy, bywa zdeprecjonowanie rywala, jego dekoncentracja, poniżenie, ośmieszenie, a nawet upokorzenie. Agresja odnotowywana w mediach przybiera rozmaite formy, od uprzedzeń na tle religijnym lub narodowościowym, poprzez drobne złośliwości, po nawet znęcanie się nad słabszym fizycznie lub psychicznie zawodnikiem. Media masowe podglądają mniej lub bardziej efektowne zdarzenia, po czym szczegółowo je opisują, nie pomijając elementów drastycznych i brutalnych, jak też naruszających godność osobistą prezentowanych bohaterów. Relacje dziennikarskie opatrywane są licznymi - często naturalistycznymi w swojej wymowie - zdjęciami.

Podglądaniu agresji w sporcie sprzeciwiał się Andrzej Ostrowski, dziennikarz sportowy, sprawozdawca i komentator. Ostrowski zwracał uwagę, że obowiązkiem reportera jest walka z chuligaństwem, a nie reklamowanie tego zjawiska. Zdaniem Ostrowskiego współczesna prasa powinna raczej analizować zaistniałą sytuację, poszukiwać jej przyczyn, a nie epatować czytelników kolejnymi zajściami.

Podobnie jak Andrzej Ostrowski, przed bezrefleksyjnym relacjonowaniem wszelkich zajść, które mają miejsce w sporcie i w związku ze sportem, przestrzegał socjolog i filozof, Lech M. Nijakowski. Nijakowski sugerował nawet, że autorzy niektórych artykułów ponoszą odpowiedzialność za eskalację przemocy, która powodowana jest brakiem profesjonalizmu w mediach, czyli na przykład zbędnym i niebezpiecznym wyolbrzymianiem opisywanych zdarzeń. ${ }^{18} \mathrm{Na}$ ów naganny sposób przekazu i na sam przekaz negatywnych treści zwraca również uwagę Kodeks Etyki Dziennikarskiej Stowarzyszenia Dziennikarzy Polskich, który pochyla się nad potencjalnymi konsekwencjami epatowania scenami przemocy w mediach. Sprawa agresji w mediach została podjęta również w Dziennikarskim Kodeksie Obyczajowym Stowarzyszenia Dziennikarzy Rzeczpospolitej Polskiej. W imię zminimalizowania zainteresowania mediów negatywnymi zjawiskami w sporcie powstał jeszcze inny zbiór zasad, tj. kodeks ustalający zasady pracy dziennikarza w sytuacji kryzysowej, czyli miedzy innymi podczas zamieszek, niebezpiecznych i agresywnych zachowań uczestników wydarzeń sportowych (znany jako Zasady pracy dziennikarskiej $w$ sytuacji kryzysowej) ${ }^{19}$. Jak można więc zauważyć same stowarzyszenia dziennikarskie dostrzegają problem i próbują mu zapobiegać.

Ograniczeniu upubliczniania przez media zachowań agresywnych mogłyby też sprzyjać liczne analizy naukowe, skoncentrowane właśnie na zjawisku agresji

${ }^{18}$ Zob. L. M. Nijakowski, Przemoc jako komunikacja, „Zeszyty Prasoznawcze” 1999, nr 1-2, s. 50-54.

${ }^{19}$ K. Jakubowicz, Zasad pracy dziennikarskiej w sytuacji kryzysowej,[w:] L. M. Nijakowski, dz. cyt. , s. 32-55. 
w sporcie zawodowym i amatorskim, gdyby oczywiście zostały przeczytane i zaakceptowane. Bowiem problematyka agresji w sporcie oraz sposób pokazywania tego zjawiska w mediach, to temat dość dobrze opracowany. Od lat zajmują się nim badacze reprezentujący różnorodne specjalności, jak medioznawcy i psychologowie, pedagodzy i socjologowie, a nawet teologowie (na co wskazuje praca doktorska Tomasza Janusa - przyp. O.B.S.). Obok publikacji autorów już wymienianych, dostępne są również prace m.in. Piotra Chlebowicza Chuligaństwo stadionowe. Studium kryminologiczne ${ }^{20}$, Jerzego Dudały Fani - chuligani. Rzecz o polskich kibolach ${ }^{21}$, Zbigniewa Dziubińskiego Sport a agresja ${ }^{22}$, Radosława Kowalskiego Potomkowie Hooligana, szalikowcy. Społeczno - kulturowe źródła agresji widowni sportowych ${ }^{23}$, Piotra Piotrowskiego $O$ zachowaniach dewiacyjnych kibiców sportowych ${ }^{24}$ oraz liczne prace (przede wszystkim artykuły zamieszczane w czasopismach naukowych) badaczy zagranicznych (np. G. Armstrong ${ }^{25}$, E. Dunning ${ }^{26}$, D. Hobbs ${ }^{27}$, A. King ${ }^{28}$, E. J. Palmer ${ }^{29}$, A. Roversi ${ }^{30}$ itp. itd.), głównie anglojęzycznych. Niestety większość wspomnianych opracowań nie jest znana osobom, do których (tj. ludziom mediów) - obok wąskiego grona naukowców - jest kierowana. Pewnie dlatego różnorodne analizy, rady nie mają praktycznego zastosowania. Nieznajomość, niejednokrotnie dość prostych mechanizmów determinujących rozpowszechnianie wiadomości negatywnych, może doprowadzić do trudnych do przewidzenia konsekwencji.

Przykładowo, zdaniem kulturoznawcy, Andrzeja Gwoździa przybliżając tylko wyselekcjonowane elementy widowiska sportowego reporterzy doprowadzają do pojawienia się zjawiska tzw. „teatralizacji wydarzeń”. Ów zjawisko sprawia, że zmagania zawodników wydają się być bliższe wyreżyserowanemu spektaklowi, niż spontanicznym zmaganiom fair play. ${ }^{31}$ Charles Barr stworzył nawet hipotezę

20 P. Chlebowicz, Chuligaństwo stadionowe. Studium kryminologiczne, Warszawa 2009.

21 J. Dudała, Fani - chuligani. Rzecz o polskich kibolach, Warszawa 2004.

22 Z. Dziubiński, Sport a agresja, Warszawa 2007.

23 R. Kowalski, Potomkowie Hooligana, szalikowcy. Społeczno - kulturowe źródła agresji widowni sportowych, Toruń 2002.

24 P. Piotrowski, O zachowaniach dewiacyjnych kibiców sportowych, Torun 2000.

25 G. Armstrong, R. Harris, Football hooligans: Theory and evidence, "Sociological Review" 1991, 39(3), s. 427-458.

26 E. Dunning, P. Murphy, J. Williams, Spectator violence at football matches: towards a sociological explanation, "The British Journal of Sociology" 2001, Vol. XXXVII, issue 2, s. 221-224.

27 D. Hobbs, D. Robins, The boy done good: football violence, changes and continues, "Sociological Review" 1991, volume 39, issue 3, s. 551-579.

28 A. King, Football Hooligansm and the Practical Paradigm, "Sociology of Sport Journal" 1999, issue 16, s. 296-273.

29 E. J. Palmer, V. Thakordas, Relationship between bullying and scores on the Buss - Perry Aggression Questionnaire Among Imprisoned male Offenders, "Aggressive Behavior” 2005, volume 31, s. 56-66.

30 A. Roversi, C. Balestri, Italian ultras today: change or decline?, "European Journal on Criminal Policy and Research" 2000, issue 8, s. 183-199.

31 Zob. A. Gwóźdź, Media-eros-przemoc. Sport w czasach popkultury, [w:] „Nowe media nowe w mediach" cz. I, I. Borkowski, A. Woźny (red.), Wrocław 2005, s. 240-241. 
na temat reguł pokazywania meczu piłki nożnej. W swoich rozważaniach wskazał on na pewną prawidłowość - ,spokojne” fragmenty, i przez to mniej emocjonujące, są pokazywane w ujęciach szerszych i mniej szczegółowych, podczas gdy sytuacje podbramkowe, faule, bójki są prezentowane w dużym zbliżeniu. „W ten sposób odbiorca otrzymuje materiał skoncentrowany na wyszukiwaniu agresywnych zachowań zawodników, może podglądać mimikę ich twarzy, jak również wulgarne gesty wykonywane pod adresem drużyny przeciwnej lub sędziego." 32 Analiza zawartości polskich mediów potwierdza hipotezę Charlsa Barra; autorzy materiałów zamieszczanych na kolumnach sportowych podglądają z dużym zainteresowaniem zachowania agresywne zarówno samych zawodników ${ }^{33}$, jak i ich trenerów ${ }^{34}$, a także wszelkie zachowania nieetyczne. Interesujące dla mediów okazują się być też skutki zachowań agresywnych, jak widok ofiary, która krwawi lub ma jakiś widoczny uraz, złamanie, jest wynoszona z boiska na noszach przez służby medyczne itp. A sport w takiej odsłonie - według Ericha Fromma - ,zamiast promować dobrą wolę i pokój, w istocie forsuje jedynie agresywne współzawodnictwo i nacjonalistyczną pychę" ${ }^{35}$ - co niestety zdaje się odpowiadać niektórym konsumentom współczesnych mediów masowych, zarówno ich odbiorcom, jak i nadawcom.

Kultura masowa, w tym i współczesne media eksponują przemoc. Odbiorca - czytelnik, słuchacz, widz, internauta bywa więc systematycznie epatowany zachowaniami agresywnymi i nieetycznymi, z punktu widzenia rywalizacji sportowej. Co zapewne, w jakiś sposób zaspakaja ciekawość odbiorcy mediów, ale jednocześnie determinuje jego światopogląd, stwarza złudzenie, że w rywalizacji sportowej występuje większe nagromadzenie zachowań nagannych, niż ma to miejsce w rzeczywistości. Przed owym zachwianiem proporcji przestrzegają medioznawcy podkreślający, że ,przestępczość widziana okiem mass mediów odbiega w istotnym stopniu od obrazu zjawiska, jaki wyłania się na podstawie danych zawartych w statystykach (...)." ${ }^{36}$ Dziennikarze preferując wydarzenia medialnie atrakcyjne, w znacznym stopniu deformują prawdziwy obraz rzeczywistości, także tej sportowej.

32 Cyt. za: J. Fiske, Wprowadzenie do badań nad komunikowaniem, Wrocław 1999, s. 179.

33 Zob. M. Chojecki, Choroba wściektych legionistów, „Super Express” 15.02.2008, nr 39, s. 30; A. Kostyra, Trzeci raz złamali mu nos, „Super Express” 28.11.2008, nr 278, s. 25; Wiese chciał urwać mu głowę, „Fakt” 9.05.2008, nr 108, s. 22; Półtora roku dla Sypniewskiego, „Gazeta Wyborcza" 16.05.2008, nr 114, s. 41.

34 Zob. Sz. Rojek, To będzie koniec Scolariego?, „Super Express” 14.09.2007, nr 215, s. 30; Oto kłamca!, „Super Express” 24.10.2008, nr 250, s. 28; Scolari bił, Portugalia straci trenera?, „Gazeta Wyborcza” 14.09.2007, nr 215, s. 42; R. Stec, Birbant z piłka, , Gazeta Wyborcza” 23.10.2008, nr 249, s. 2; Pojedynek awanturników, „Fakt” 24.10.2008, nr 250, s. 22.

35 E. Fromm, Anatomia ludzkiej destrukcyjności, Poznań 1998, s. 40.

${ }^{36} \mathrm{~K}$. Witkowska, Informacja o przestępczości w środkach masowego przekazu, [w:] Znaczenie informacji $w$ spoleczeństwie obywatelskim. Wybrane aspekty prawne, J. Marszałek-Kawa (red.), Toruń 2007, s. 151. 


\section{BIBLIOGRAFIA}

Aronson E., Człowiek istota społeczna, Wydawnictwo Naukowe PWN, Warszawa 1995.

Borkowski I., Stasiuk-Krajewska K., Kształtowanie wizerunku jako narzędzie public relations, Wydawnictwo Uniwersytetu Wrocławskiego, Wrocław 2001.

Chlebowicz P., Chuligaństwo stadionowe. Studium kryminologiczne, Oficyna Wolters Kluwer business, Warszawa 2009.

Dudała J., Fani - chuligani. Rzecz o polskich kibolach, Wydawnictwo Akademickie „Żak”, Warszawa 2004.

Dziubiński Z., Sport a agresja, Salezjańska Organizacja Sportowa Rzeczpospolitej Polskiej, Warszawa 2007.

Fiske J., Wprowadzenie do badań nad komunikowaniem, Wydawnictwo Astrum, Wrocław 1999.

Fras J., Dziennikarski warsztat językowy, Wydawnictwo Uniwersytetu Wrocławskiego, Wrocław 1999.

Fromm E., Anatomia ludzkiej destrukcyjności, Dom Wydawniczy Rebis, Poznań 1998.

Fromm E., Wojna w człowieku, Agencja Wydawnicza Jacek Santorski \& CO, Warszawa 1994.

Gwóźdź A., Media-eros-przemoc. Sport w czasach popkultury, [w:] „Nowe media nowe w mediach” cz. I, I. Borkowski, A. Woźny (red.), Wrocław 2005.

Jakubowicz K., Zasad pracy dziennikarskiej w sytuacji kryzysowej, [w:] L. M. Nijakowski, Przemoc jako komunikacja, „Zeszyty Prasoznawcze” 1999.

Janus T., Zjawisko agresji $w$ widowiskach sportowych. Charakterystyka i ocena, rozprawa doktorska napisana w Katedrze Teologii Pastoralnej Fundamentalnej UKSW w Warszawie, pod kierunkiem ks. prof. J. Przybyłowskiego, Warszawa 2012, s. 7-8.

Kapuściński R., Wojna futbolowa, Wydawnictwo Czytelnik, Warszawa 2003.

Kowalski R., Potomkowie Hooligana, szalikowcy. Społeczno - kulturowe źródła agresji widowni sportowych, Wydawnictwo Adam Marszałek, Torun 2002.

Lipoński W., Olimpizm dla każdego, Wydawnictwo AWF, Poznań 2000.

Mazur Z., Organista N., Poziom agresywności kobiet uprawiajacych sporty rodzajowo męskie $i$ kobiece, „Journal of education, health and sport” vol. 5, nr 5 (2015).

McLuhan M., Zrozumieć media. Przedtużenia człowieka, Wydawnictwa Naukowo-Techniczne, Warszawa 2004.

Nijakowski L. M., Przemoc jako komunikacja, „Zeszyty Prasoznawcze” 1999, nr 1-2.

P. Piotrowski, O zachowaniach dewiacyjnych kibiców sportowych, Wydawnictwo Adam Marszałek, Toruń 2000.

Rivers W. L., Mathews C., Etyka środków przekazu, Wydawnictwo Artystyczne i Filmowe Ars Polona, Warszawa 1995.

Witkowska K., Informacja o przestępczości w środkach masowego przekazu, [w:] Znaczenie informacji $w$ społeczeństwie obywatelskim. Wybrane aspekty prawne, J. Marszałek-Kawa (red.), Wydawnictwo Adam Marszałek, Torun 2007.

Życiński J. abp, Kuszenie Pana Cogito, Wydawnictwo UMCS, Lublin 2001.

\section{NETOGRAFIA}

Awantura po meczu siatkarzy z Iranem. Trenerom i zawodnikom puścity nerwy, www.sport.dziennik. $\mathrm{pl} /$ siatkowka/artykuly/528406.

Jasiecki K., Wyczyn, pieniądze, polityka, rozmowa z prof. K. Doktórem, www.decydent.pl/meandry-sportu/. 
Odpowiedziatem agresja na agresję. Hriwko nie przeprosi Kittela, www.eurosport.onet.pl/kolarstwo/odpowiedziałem-agresja-na agresję-hriwko-nie przeprosi-kittela/8px26w.

Rio 2016: obraźliwe gesty polskich siatkarzy przyczyna awantury po meczu z Iranem?, www. eurosport.onet.pl/rio-2016/siatkowka/rio-2016.

Rio 2016. Polska - Iran. Irańscy kibice strasza Michała Kubiaka,www.sport.pl/igrzyska-olimpijskie/1,154863,20524603.

\section{Streszczenie}

Autorka tekstu analizuje sposób dokonywania selekcji oraz tworzenia materiałów dziennikarskich poruszających problem agresji w sporcie. Zwraca uwagę na atrakcyjność, ale i zarazem niebezpieczeństwo pojawiające się podczas upubliczniania tego typu artykułów. Zastanawia się nad etiologią problemu, tj. kto generuje większy popyt na agresję: odbiorcy mediów, nadawcy - dziennikarze, a może sami bohaterowie - sportowcy?

Słowa kluczowe: agresja w sporcie, dziennikarstwo sportowe, news

\section{MEDIA AND THE PHENOMENON OF AGGRESSION IN SPORT}

\section{Sum mary}

The author of the text analyzes how to make selections and create journalistic materials that address the problem of aggression in sport. It draws attention to the attractiveness, but also the dangers of publishing such articles. He wonders about the etiology of the problem, who generates greater demand for aggression: media recipients, broadcasters - journalists, and maybe the heroes themselves - athletes?

Keywords: Aggression in sport, sports journalism, news 